\title{
Hydrochemical Characteristics and Quality Assessment of Shallow Groundwater in Yangtze River Delta of Eastern China
}

Taotao Lu

Bayreuth University: Universitat Bayreuth

Runzhe Li

Shandong Agricultural University

Aira Sacha Nadine Ferrer

Bayreuth University: Universitat Bayreuth

Shuang Xiong

Wuhan Zondy W\&R Environmental Technology Co.

\section{Pengfei Zou}

Yantai New Era Health Industry Chemical Co.

Hao Peng ( $\sim$ penghao@cug.edu.cn)

China University of Geosciences

\section{Research Article}

Keywords: Yangtze River Delta, Hydrochemistry, Shallow groundwater quality, Health risk assessment

Posted Date: October 18th, 2021

DOI: https://doi.org/10.21203/rs.3.rs-931598/v1

License: (1) This work is licensed under a Creative Commons Attribution 4.0 International License. Read Full License

Version of Record: A version of this preprint was published at Environmental Science and Pollution Research on March 28th, 2022. See the published version at https://doi.org/10.1007/s11356-022-19881w. 


\section{River Delta of eastern China}

3

4

${ }^{1}$ Department of Hydrology, Bayreuth Center of Ecology and Environmental Research

${ }^{2}$ Faculty of Public Administration, Shandong Agriculture University, Taian, 271011, China

${ }^{3}$ Wuhan Zondy W\&R Environmental Technology Co., Ltd, Wuhan, 430078, China 
Abstract

21 The water resource is highly demanded in the Yangtze River Delta with a developed

22 economy. Long-term exploitation has posed threats of artificial pollution and seawater intrusion

23 to the shallow groundwater. This study aimed to reveal the hydrochemical characteristics and

24 health risks of shallow groundwater in the coastal plain of the Yangtze River Delta. Also,

25 possible factors affecting groundwater quality were discussed. Methods, such as typical

26 hydrochemical tests, water quality assessment and health risk models, were applied to achieve

27 the study targets. The results showed that the shallow groundwater was slightly alkaline, and the

28 average values of total dissolved solids (TDS) and total hardness (TH) were $930.74 \mathrm{mg} / \mathrm{L}$ and

$29436.20 \mathrm{mg} / \mathrm{L}$, respectively. The main hydrochemical types of groundwater were $\mathrm{Ca}+\mathrm{Mg}-\mathrm{HCO}_{3}$

30 and $\mathrm{Ca} / \mathrm{Na}-\mathrm{HCO}_{3}$, accounting for $44.3 \%$ and $47.5 \%$, respectively. In addition, As concentration

31 was generally high, with a mean value of $0.0115 \mathrm{mg} / \mathrm{L}$. The principal factors affecting the

32 groundwater components include water-rock interactions (especially silicate), cation exchange,

33 seawater intrusion and human activities. As in the groundwater is strongly influenced by the

34 redox of $\mathrm{Fe}, \mathrm{Mn}$, and $\mathrm{NO}_{3}{ }^{-}$. The results of the groundwater quality evaluation indicated that the

35 shallow groundwater in some regions was unsuitable for drinking and agricultural irrigation.

36 Health risk assessment showed that $44.3 \%$ of the water samples had significant health risks,

37 which was attributed to the high As concentration. Therefore, it is urgent to establish long-term

38 As monitoring to maintain sustainable groundwater management and drinking water safety. The 
39 results of this study can provide essential data for water resource management and human health

40 protection in the Yangtze River Delta.

41 Keywords: Yangtze River Delta; Hydrochemistry; Shallow groundwater quality; Health risk

42 assessment

43

44 1. Introduction

45 Shallow groundwater is a crucial water source for industrial and agricultural production as

46 well as daily life due to its shallow buried depth and easy accessibility (Li et al. 2020; Liu et al.

47 2021d). The shallow groundwater quality plays a critical role in urban development and resident

48 health. However, a growing number of studies have proposed that shallow groundwater in many

49 places became unsuitable for drinking and production resulting from the impact of the natural

50 environment and human activities (Hao et al. 2020; Lima et al. 2020). Water salinization and the

51 enrichment of some harmful trace elements, like As, F, etc., in shallow groundwater pose a

52 danger to both ecological safety and physical health (Liu et al. 2021d; Long et al. 2021; Wang et

53 al. 2020; Wu and Sun 2016). In recent years, groundwater quality and health risk assessment

54 have become an essential part of research on medical geology (Selinus et al. 2016). The

55 distributions, sources, and contamination levels of inorganic components in shallow groundwater

56 are the foundation for pollution evaluation and management.

57 The evolution of shallow groundwater in estuary and delta areas is quite complex. Due to 
58 the influence of weather, depositional environment, and anthropological activities, the shallow

59 groundwater environment is fragile (Zhi et al. 2021). Cao et al. (2020) found that the

60 groundwater salinization and nitrate contamination in estuary and delta areas in Qinhuangdao

61 city in northern China were caused by seawater infiltration and agricultural pollution. Hou et al.

62 (2020) proposed that the discharge of domestic and industrial wastewater during urban

63 development had led to increased Mn concentration in shallow groundwater in the Pearl River

64 Delta plain. More and more studies have revealed growing deterioration of shallow groundwater

65 quality in estuary and delta areas (Li et al. 2018). These studies analyzed the hydrogeochemical

66 features and the evolution of groundwater quality. Still, less attention has been paid to the impact

67 of groundwater quality on human health.

68 The Yangtze River Delta plain is one of the fastest growing urban areas with the most

69 developed economy in China. Groundwater exploitation is increasing year by year as a result of

70 rapid population growth. Due to its unique geographical and geological environment, previous

71 studies mainly focused on ground subsidence caused by groundwater extraction (Ma et al. 2018).

72 Even though the Yangtze River Delta plain has abundant groundwater resources, human

73 activities have led to a remarkable deterioration in water quality (Wu et al. 2014). In addition, the

74 groundwater buried depth is relatively small in this area; thus, high TDS in groundwater is found

75 due to the intense evaporation, and the value of TDS is on an upward trend, even tending towards

76 salinization (Zhao et al. 2017). Meanwhile, the research on the variation of shallow groundwater 
77 quality in the Yangtze River Delta coastal plain proposed that seawater intrusion contributed to

78 groundwater salinization and exerted a substantial influence on groundwater quality according to

79 the analysis of $\mathrm{Sr}, \mathrm{O}$, and $\mathrm{H}$ isotopes in groundwater (Mao et al. 2020). Although the

80 deterioration of water quality in the Yangtze River Delta has attracted much attention, there are

81 still no studies on shallow groundwater quality and health risks. In particular, thus far, the spatial

82 distributions and sources of trace elements, groundwater quality and related controlling factors

83 are unknown in the Yangtze River Delta plain.

84 Based on these considerations, shallow groundwater samples were taken from the coastal

85 plain in the Yangtze River Delta; then the dissolved inorganic ingredients in the groundwater

86 were systematically analyzed to achieve the following targets: (1) identify the hydrochemical

87 characteristics of shallow groundwater in this area; (2) evaluate shallow groundwater quality and

88 possible impacts on physical health. These findings can provide valuable information for water

89 resource management and physical health protection in the Yangtze River Delta.

90

91 2. Materials and methods

92 2.1. Study area description

93 The study area, located in Jiangsu province, China, is flanked by the Yellow Sea to the east

94 and the Yangtze River to the south. It is a typical estuarine delta plain. The topography of this

95 area is, in general, flat and the altitude decreases from west to east. The regional climate is the

96 humid subtropical monsoon climate with average annual precipitation and evaporation of 1050.8 
$97 \mathrm{~mm}$ and $877.2 \mathrm{~mm}$, respectively.

98 The shallow aquifers in the study area consist of the Quaternary Holocene estuarine and

99 coastal unconfined aquifer groups. The porous media is constituted by gray, gray-green silt and

100 silty sub-sandy loam. The lower bedding layer is comprised of shallow marine silty sub-clay

101 deposits, and its bottom slab is buried at a depth of about $30 \mathrm{~m}$ with an average thickness of 27

$102 \mathrm{~m}$. The aquifers change from unconfined aquifers to slightly confined aquifers towards the east;

103 simultaneously, the groundwater quality gradually becomes saline (Mao et al. 2020). The

104 primary recharge sources of shallow groundwater are atmospheric precipitation and inflow of the

105 Yangtze River and its branches. Since the terrain is relatively flat, the groundwater flow in

106 aquifers is sluggish under the control of topography. Groundwater discharge mainly includes

107 near-surface evaporation and artificial exploitation. Overall, in the research area, the water

108 quality of shallow groundwater is quite complicated because the groundwater was salinized by

109 Holocene marine intrusion and then gradually desalinated by the large quantity of fresh water

110 from the Yangtze River and atmospheric precipitation. In addition, the Yangtze River Delta is one

111 of the most densely inhabited regions in China. Seawater intrusion resulting from a large amount

112 of groundwater extraction and industrial and agricultural pollution have caused a non-negligible

113 impact on the shallow groundwater in this area (Zhao et al. 2017).

114

1152.2 Groundwater sample collection and measurement 
116 In this study, 61 water samples, all of which were shallow groundwater, were taken from the

117 domestic wells in the study area in August 2019. The depth of these wells was less than $10 \mathrm{~m}$.

118 Meanwhile, 1 seawater sample was obtained from the sea near the study area, and 1 rainwater

119 sample was taken in the middle of the study area (see Fig 1). The specific sampling procedure

120 based on our previous studies (Peng et al. 2021a; Peng et al. 2021b) could be found in the

121 supplementary material. The concentrations of trace elements and major elements in the water

122 samples were obtained through ion chromatography, the inductively coupled plasma emission

123 mass spectrometer and standard $\mathrm{HCl}$ titration. The measurement process was provided in the

124 supplementary material. In addition, some parameters like $\mathrm{pH}$ and TDS were measured on-site

125 by a portable analyzer.

126 The statistical analysis of obtained data was carried out by SPSS software (IBM 23). During

127 the correlation analysis of each component in groundwater, in the first place, to determine

128 whether the data conform to a normal distribution, the Kolmogorov-Smirnov (K-S) test and

129 Shapiro-wilk test were applied separately. However, the hydrochemical indicators except for $\mathrm{pH}$

130 were not in accordance with the normal distribution; thereby, the Spearman model was adopted

131 for correlation analysis. At last, the spatial distribution of hydrochemical indicators was drawn

132 by ArcGIS software (version 10.5) according to the inverse distance weighting interpolation.

133

$134 \quad 2.3$ Groundwater quality assessment 
136 Sodium adsorption ratio (SAR) and sodium percentage ( $\mathrm{Na} \%$ ), which can be calculated by

137 the equations (Eqs.) (1-2), are usually used to estimate whether groundwater is suitable for

138 irrigation (Long and Luo 2020). Na plays a vital role in irrigation water classification because of

139 its interaction with the soil. Na with a high concentration in irrigation water is readily adsorbed

140 on clay minerals in the soil, replacing $\mathrm{Mg}$ and $\mathrm{Ca}$. Besides, the ion exchange of $\mathrm{Na}$ with $\mathrm{Mg}$ and

141 Ca reduces soil permeability. SAR is considered to be an essential indicator for the evaluation of

142 irrigation water quality. When this indicator is high, the groundwater is not suitable for irrigation.

$143 \quad \mathrm{Na} \%=\left(\frac{\mathrm{Na}+\mathrm{K}}{\mathrm{Ca}+\mathrm{Mg}+\mathrm{Na}+\mathrm{K}}\right) \times 100 \%$

$144 \mathrm{SAR}=\frac{\mathrm{Na}}{\sqrt{\frac{\mathrm{Ca}+\mathrm{Mg}}{2}}}$

\section{$146 \quad$ 2.3.2 Groundwater quality assessment for drinking purpose}

147 The water quality index (WQI) is widely used for drinking water quality assessment since

148 Horton proposed it in the 1960s. The critical point of WQI calculation is to determine the weight

149 of each water quality indicator because minor changes in weight will change the assessment

150 result (Zhang et al. 2020). The methods that are commonly used to determine the weight are the

151 objective weighting method (e.g., entropy-weighted method and criteria importance though inter-

152 criteria correlation method) (Zhang et al. 2021) and the subjective weighting method (e.g., order

153 relation analysis method) (Gao et al. 2020). The subjective weighting method is based on the 
154 investigator's actual experience, which brings multiple uncertainties to the result due to the

155 different preferences of different investigators (Islam et al. 2020). Although the objective

156 weighting method does not rely on subjective judgment and has a solid mathematical basis, it

157 fails to reflect the degrees of importance of different indicators to the decision-maker

158 (Narayanamoorthy et al. 2020). Therefore, this study used the integrated-weight method, which

159 combines the subjective and objective weighting methods.

160 In the subjective weighting part, the weighting value $\left(w_{\mathrm{j} 1}\right)$ of the water quality indicator is

161 determined by its relative perceived effect and importance on human health, which can be

162 calculated by the following Eq.(3).

$163 \quad w_{\mathrm{j} 1=} \frac{P_{\mathrm{j}}}{\sum P_{\mathrm{j}}}$

164 Where $P_{\mathrm{j}}$ is the importance score of water quality indicator $\mathrm{j}$, which varies in the range of $1-5$ (1

165 shows the minimal impact on water quality; 5 indicates the most significant impact on water

166 quality), for example, heavy metals, such as $\mathrm{As}, \mathrm{Cd}, \mathrm{Cr}$, and $\mathrm{Pb}$, are harmful to physical health,

167 so their $P$ values are 5. The importance score of the different hydrochemical indicators can be

168 found in Table S1.

169 In the objective weighting part, the weight of water quality indicator $\mathrm{j}\left(w_{\mathrm{j} 2}\right)$ is determined

170 using the entropy weight method. The specific procedures are as follows:

171 In the first place, the initial data are standardized to obtain initial matrix X (Eq.(4)). 
$172 \quad \mathrm{X}=\left[\begin{array}{ccc}\mathrm{x}_{11} & \cdots & \mathrm{x}_{1 \mathrm{n}} \\ \vdots & \ddots & \vdots \\ & & \\ \mathrm{x}_{\mathrm{m} 1} & \cdots & \mathrm{x}_{\mathrm{mn}}\end{array}\right]$

173 Where $\mathrm{m}$ is the total number of groundwater samples; $\mathrm{n}$ is the total number of measured

174 hydrochemical indicators in one sample.

175 After that, the initial matrix $\mathrm{X}$ is reversely normalized with Eq. (5) to get the standard

176 matrix Y (Eq.(6)).

$177 \quad \mathrm{y}_{\mathrm{ij}}=\frac{\left(\mathrm{x}_{\mathrm{ij}}\right)_{\max }-\mathrm{x}_{\mathrm{ij}}}{\left(\mathrm{x}_{\mathrm{ij}}\right)_{\max }-\left(\mathrm{x}_{\mathrm{ij}}\right)_{\min }}$

$178 \quad \mathrm{Y}=\left[\begin{array}{ccc}\mathrm{y}_{11} & \cdots & \mathrm{y}_{1 \mathrm{n}} \\ \vdots & \ddots & \vdots \\ \mathrm{y}_{\mathrm{m} 1} & \cdots & \mathrm{y}_{\mathrm{mn}}\end{array}\right]$

179 At last, the $w_{\mathrm{j} 2}$ are obtained by Eqs. (7-9) (Islam et al., 2020):

$180 \quad y_{\mathrm{j}}=\frac{\mathrm{y}_{\mathrm{ij}}+10^{-4}}{\sum_{\mathrm{j}=1}^{\mathrm{m}}\left(\mathrm{y}_{\mathrm{ij}}+10^{-4}\right)}$

$181 \quad e_{\mathrm{j}}=-\frac{1}{\operatorname{lnm}} \sum_{\mathrm{i}=1}^{\mathrm{m}} \mathrm{y}_{\mathrm{j}} \ln \mathrm{y}_{\mathrm{j}}$

$182 \quad w_{\mathrm{j} 2}=\frac{1-\mathrm{e}_{\mathrm{j}}}{\sum_{\mathrm{j}=1}^{\mathrm{n}}\left(1-\mathrm{e}_{\mathrm{j}}\right)}$

183 Based on the Eqs. (3 and 9), the integrated weight can be calculated by following Eq.

$184 \quad W_{\mathrm{j}}=\frac{w_{\mathrm{j} 1} \times w_{\mathrm{j} 2}}{\sum_{\mathrm{j}=1}^{\mathrm{n}} w_{\mathrm{j} 1} \times w_{\mathrm{j} 2}}$

185 After calculating the weights $\left(w_{\mathrm{j} 1}, w_{\mathrm{j} 2}\right.$, and $W_{\mathrm{j}}$ values are provided in Table $\left.\mathrm{S} 1\right)$, the WQI

186 value is calculated by Eq. (11) (see Table S2).

$187 \quad \mathrm{WQI}=\sum_{\mathrm{j}=1}^{\mathrm{n}}\left[W_{\mathrm{j}} \times\left(\frac{C_{\mathrm{j}}}{S_{\mathrm{j}}}\right) \times 100\right]$ 
188 where $C_{\mathrm{j}}$ is the value of water quality indicator $\mathrm{j}$ in the water sample; $S_{\mathrm{j}}$ is the upper limit of the

189 water quality indicator $\mathrm{j}$ in the national standard for drinking water quality (GB 5749-2006). The

190 groundwater can be classified into five categories based on the calculated WQI value: (1)

191 excellent (WQI < 25); (2) good $(25<\mathrm{WQI}<50)$; (3) medium $(50<\mathrm{WQI}<100)$; (4) poor $(100<$

$192 \mathrm{WQI}<150)$ and (5) extremely poor $(\mathrm{WQI}>150)$.

193 Hazard Index (HI) is the most commonly used method to evaluate the risk of trace elements

194 in groundwater to human health. Because children are the most sensitive to the exposed heavy

195 metals, the analysis in this study focused on the children's HI (Chen et al. 2020). There are two

196 main exposure pathways to the contaminants in drinking water: dermal absorption (e.g., bathing)

197 and oral ingestion (e.g., drinking water). Therefore, the health risk evaluation of components in

198 groundwater was estimated based on these two main pathways in this research. The specific

199 equations to calculate the HI value can be found in the supplementary material. Table S2

200 presented the calculated HI values. Overall, when HI is less than 1, there is no health hazard.

201 Even if a health hazard is produced, it is negligible and difficult to be detected. In contrast, HI >

2021 means an adverse effect on health.

203

204 3. Results and discussion

2053.1 Hydrochemical features of shallow groundwater in the study area

206 The statistical characteristics of the main components in shallow groundwater in the study 
207 area are shown in Table 1. The $\mathrm{pH}$ of the groundwater samples varied between 6.90 and 7.90,

208 with a mean of 7.31, indicating that the groundwater in the study area is slightly alkaline. The

209 TDS fell in the range of $411.45-2361.77 \mathrm{mg} / \mathrm{L}$, with an average of $930.74 \mathrm{mg} / \mathrm{L} .67 .21 \%$ of the

210 groundwater samples were freshwater (TDS $<1000 \mathrm{mg} / \mathrm{L}$ ). The $\mathrm{TH}\left(\mathrm{CaCO}_{3}\right)$ was in the range of

$211181.63-897.74 \mathrm{mg} / \mathrm{L}$, and the mean TH was $436.20 \mathrm{mg} / \mathrm{L}$. Based on the TDS and TH values,

212 the groundwater in the study area fell into moderately hard, hard, and very hard water (see Fig.

213 S1(a)). From Fig. S2, it could be found that the contents of major cations followed the order of

$214 \mathrm{Na}>\mathrm{Ca}>\mathrm{Mg}>\mathrm{K}$, with mean values of $124.08 \mathrm{mg} / \mathrm{L}, 87.46 \mathrm{mg} / \mathrm{L}, 52.21 \mathrm{mg} / \mathrm{L}$, and 22.80

$215 \mathrm{mg} / \mathrm{L}$, respectively. Among them, the maximum Na content was $482.79 \mathrm{mg} / \mathrm{L}$, which exceeded

216 its upper limit $(250 \mathrm{mg} / \mathrm{L})$ in the national drinking water quality standard (GB5749-2006).

217 Similarly, the contents of main anions followed the sequence of $\mathrm{HCO}_{3}{ }^{-}>\mathrm{Cl}^{-}>\mathrm{SO}_{4}{ }^{2-}>\mathrm{NO}_{3}{ }^{-}$,

218 with average values of $543.87 \mathrm{mg} / \mathrm{L}, 117.99 \mathrm{mg} / \mathrm{L}, 96.12 \mathrm{mg} / \mathrm{L}$ and $32.29 \mathrm{mg} / \mathrm{L}$, respectively.

219 The maximum values of $\mathrm{Cl}^{-}, \mathrm{SO}_{4}{ }^{2-}$ and $\mathrm{NO}_{3}{ }^{-}$contents were $806.00 \mathrm{mg} / \mathrm{L}, 271.90 \mathrm{mg} / \mathrm{L}$, and

$220 \quad 139.77 \mathrm{mg} / \mathrm{L}$, all of which exceeded the upper limits in the drinking water standard (GB5749-

221 2006). In addition, the Piper diagrams indicated that the shallow groundwater in the study area

222 had four different types (see Fig. S1(b)). The main types were $\mathrm{Ca}+\mathrm{Mg}-\mathrm{HCO}_{3}$ and $\mathrm{Ca} / \mathrm{Na}-$

$223 \mathrm{HCO}_{3}$, accounting for $44.3 \%$ and $47.5 \%$, respectively, while the remaining ones were $\mathrm{Na}-\mathrm{HCO}_{3}$

224 and $\mathrm{Na}-\mathrm{Cl}$.

225 By analyzing the spatial distribution of hydrochemical indicators, the features of 
226 groundwater hydrochemistry can be more clearly understood in the study area. As indicated in

227 Fig. 2(a), the TDS values of shallow groundwater ranged from $400 \mathrm{mg} / \mathrm{L}$ to $1000 \mathrm{mg} / \mathrm{L}$; and the

228 groundwater samples with high TDS were distributed in the middle part of the study area and

229 coastal regions. In terms of TH (see Fig. 2(b)), groundwater with relatively high TH was located

230 in the west part of the study area, such as Rugao city and Nantong city; In contrast, the

231 groundwater in the east part had low $\mathrm{TH}$. The spatial distributions of $\mathrm{Na}$ and $\mathrm{Cl}^{-}$were similar, as

232 shown in Fig. 2(c, d), with the highest concentrations in the middle part of the study area and

233 coastal regions, while their concentrations were low in the west. The spatial distribution of $\mathrm{SO}_{4}{ }^{2-}$

234 was different from that of $\mathrm{Na}^{2}$ and $\mathrm{Cl}^{-}$, with relatively high levels in the west and relatively low

235 levels in the east (see Fig. 2(e)). The spatial distribution of $\mathrm{NO}_{3}{ }^{-}$varied irregularly; the relatively

236 high $\mathrm{NO}_{3}{ }^{-}$levels were found in the agricultural regions of Rugao city, Haimen city, and Qidong

237 city (see Fig. 2(f)).

238 The statistical characteristics of trace elements in shallow groundwater can be found in

239 Table 1 and Fig. S2(b). The average concentrations of trace elements followed the below order:

$240 \mathrm{Sr}>\mathrm{Br}>\mathrm{F}^{-}>\mathrm{B}>0.1 \mathrm{mg} / \mathrm{L}>\mathrm{Ba}>\mathrm{Al}>\mathrm{Fe}>\mathrm{Zn}>\mathrm{Mn}>\mathrm{Li}>\mathrm{As}>0.01 \mathrm{mg} / \mathrm{L}>\mathrm{Cu}>\mathrm{Se}>\mathrm{Cr}=$

$241 \mathrm{Ni}>\mathrm{Mo}>0.001 \mathrm{mg} / \mathrm{L}>$ Others $(\mathrm{Co}, \mathrm{Ag}, \mathrm{Cd}, \mathrm{Sn}, \mathrm{Sb}, \mathrm{W}, \mathrm{Tl}, \mathrm{Pb}$ and $\mathrm{Be}) . \mathrm{Sr}, \mathrm{Br}, \mathrm{F}^{-}$and $\mathrm{B}$ were

242 the main trace elements and their average values (maximum values) were $0.4975 \mathrm{mg} / \mathrm{L}(0.9882$

$243 \mathrm{mg} / \mathrm{L}), 0.3729 \mathrm{mg} / \mathrm{L}(2.6350 \mathrm{mg} / \mathrm{L}), 0.3470 \mathrm{mg} / \mathrm{L}(1.0790 \mathrm{mg} / \mathrm{L})$ and $0.2888 \mathrm{mg} / \mathrm{L}(1.0065$

$244 \mathrm{mg} / \mathrm{L}$ ), respectively. It is also worth noting that the maximum values of $\mathrm{F}^{-}, \mathrm{B}, \mathrm{Al}, \mathrm{Fe}, \mathrm{Mn}, \mathrm{As}, \mathrm{Se}$, 
$245 \mathrm{Cr}$ and $\mathrm{Ni}$ exceeded the upper limit in the drinking water standard (GB5749-2006).

246 The spatial distributions of typical trace elements are illustrated in Fig. 3. The groundwater

247 samples from coastal regions contained higher $\mathrm{F}^{-}$levels than non-coastal regions in the study

248 area. Similarly, the groundwater samples with higher B content were distributed in the coastal

249 regions; the highest B content was found in the western part of Haimen city. The groundwater

250 samples containing the highest $\mathrm{Al}, \mathrm{Fe}$, and $\mathrm{Ni}$ concentrations were from the central and

251 southeastern regions. In addition, groundwater having the highest Mn level was found in Rugao

252 city. The As level in shallow groundwater was generally high; in particular, Nantong city and the

253 southeastern part of Qidong city had higher As concentrations than other regions. Except for one

254 water sample from the north of Qidong city containing high Se levels, the Se concentrations in

255 the rest regions were below $0.002 \mathrm{mg} / \mathrm{L}$.

2573.2 Shallow groundwater genesis and pollution sources in the study area

258 In order to obtain the shallow groundwater genesis, the ratios of different components in

259 groundwater were calculated and analyzed. Gibbs diagram can reflect the degree of influence of

260 evaporation,water-rock interaction, and precipitation on the evolution of groundwater

261 hydrochemistry (Gibbs 1970). In this study, most groundwater samples were found in the rock

262 dominance and evaporation zones (see Fig. S3), which means groundwater hydrochemistry is

263 mainly influenced by rock weathering. At the same time, evaporation and concentration also play 
264 a crucial role in groundwater quality (Samsudin et al. 2008).

265 Carbonate rock, silicate rock, and evaporite rock are the primary weathered materials, and

266 different rocks will lead to varying levels of ions in the groundwater after weathering. As shown

267 in Fig. S4(a, b), the water-rock interaction in the study area was largely controlled by the

268 weathering of silicate rocks. In addition, the ratio of $(\mathrm{Ca}+\mathrm{Mg}) /\left(\mathrm{HCO}_{3}{ }^{-}+\mathrm{SO}_{4}{ }^{2-}\right)$ could denote the

269 effect of dissolution of carbonate rocks and gypsum on the water quality (Liu et al. 2021c).

270 According to Fig. S4(c), some points fell on the 1:1 line, suggesting that the dissolution of

271 carbonate rocks and gypsum also contributed to the evolution of groundwater quality. As

272 illustrated in Fig. S4(d), $\mathrm{Ca}$ and $\mathrm{Mg}$ in most groundwater samples derived from the dissolution of

273 dolomite and calcite (Argamasilla et al. 2017). Furthermore, most groundwater samples had

$274 \mathrm{Na} / \mathrm{Cl}^{-}$ratios close to the seawater-freshwater mixing line in Fig. 4(a), indicating that the main

275 source of $\mathrm{Na}^{2}$ and $\mathrm{Cl}^{-}$is seawater intrusion. For the purpose of further evaluating the extent of

276 seawater intrusion, seawater fraction $\left(f_{\text {sea }}\right)$ is introduced. Because $\mathrm{Cl}^{-}$, a stable tracer, is less

277 affected by ion exchange, the $\mathrm{Cl}^{-}$concentration is usually utilized to calculate $f_{\text {sea }}$ value through

278 Eq.(12) (Argamasilla et al. 2017; Mountadar et al. 2018).

$279 f_{\text {sea }}=\frac{C_{\mathrm{Cl}, \text { sample }}-C_{\mathrm{Cl}} \text { fresh }}{C_{\mathrm{Cl}, \text { sea }}-C_{\mathrm{Cl}, \text { fresh }}}$

280 Where $C_{\mathrm{Cl}}$, sample, $C_{\mathrm{Cl}}$, sea, and $C_{\mathrm{Cl}}$, fresh are the $\mathrm{Cl}^{-}$concentrations in groundwater sample, seawater,

281 and freshwater, respectively.

282 It is assumed that the groundwater sample having the lowest TDS is freshwater (Han et al. 
283 2015). Because of the high solubility of $\mathrm{Cl}^{-}$, the dissolution of aquifer bedrock and seawater

284 intrusion are its primary source (Argamasilla et al. 2017). Fig. 4(b) showed that the $f_{\text {sea }}$ varied

285 with TDS, and the $f_{\text {sea }}$ was in the range of $0-6.42 \%$, with a mean of $0.86 \%$, suggesting that

286 moderate seawater intrusion has impacted the shallow groundwater. Besides, TDS was not linear

287 with $f_{\text {sea }}\left(\mathrm{R}^{2}=0.71\right)$, which also reflects that the water-rock interaction also controls the

288 groundwater quality (Najib et al., 2016).

289 In addition, the theoretical concentration of ion $i\left(C_{i, \text { mix }}\right)$ in the combination of seawater and

290 freshwater can be calculated with $f_{\text {sea }}$ value by Eq.(13) (Appelo and Postma 2005).

$291 C_{i, \text { mix }}=f_{\text {sea }} \times C_{i, \text { sea }}+\left(1-f_{\text {sea }}\right) \times C_{i, \text { fresh }}$

292 Where $C_{i}$, sea and $C_{i}$, fresh are the concentrations of ion $i$ in the seawater and freshwater.

$293 \mathrm{Br}^{-}$in groundwater in coastal regions is mainly from seawater (Zhao et al. 2017), so the

294 accuracy of the $f_{\text {sea }}$ can be assessed by comparing the calculated $\mathrm{Br}^{-}$concentration with its

295 measured concentration. As seen in Fig. 4(c), it can be found that the calculated and measured

296 concentrations of $\mathrm{Br}^{-}$were approximately distributed around the 1:1 line, indicating that the

297 calculated $f_{\text {sea }}$ is reliable. Nevertheless, most points failed to lie on the 1:1 line, which resulted

298 from the effect of seawater and freshwater mixture. In Fig. S5, the relatively high $f_{\text {sea }}$ were

299 mainly distributed in the coastal regions and the middle part of the study area. Therefore,

300 seawater intrusion is more severe in these regions. Also, the distribution of $f_{\text {sea }}$ was in accordance

301 with that of $\mathrm{Cl}^{-}$and $\mathrm{Na}$, proving that the high $\mathrm{Na}$ and $\mathrm{Cl}^{-}$levels in the study area result from the 
302 sea. It is noteworthy that the $f_{\text {sea }}$ value in the eastern part of Nantong city was even higher than

303 that in the coastal regions. This is because Nantong city is the most densely populated region in

304 the study area, with high water consumption for industry and agriculture; thus, the massive

305 exploitation of shallow groundwater makes this area suffer from the most severe seawater

306 intrusion.

$307 \mathrm{NO}_{3}{ }^{-}$in groundwater mainly comes from agricultural production and domestic sewage. It is

308 expected that the $\mathrm{Cl}^{-} / \mathrm{Na}$ and $\mathrm{NO}_{3}{ }^{-} / \mathrm{Na}$ ratios are high in contaminated groundwater (Liu et al.

309 2021c). Fig. 4(d) shows that agricultural activities did exert an important impact on shallow

310 groundwater quality. In addition, the ratio between $\mathrm{Na}+\mathrm{K}^{-} \mathrm{Cl}^{-}$and $\mathrm{HCO}_{3}{ }^{-}+\mathrm{SO}_{4}{ }^{2-}-\mathrm{Ca}-\mathrm{Mg}$ is

311 commonly utilized to identify the influence of the cation exchange in groundwater systems (Liu

312 et al. 2021b). The ratios of most water samples were near the 1:1 line, and $\mathrm{Na}+\mathrm{K}-\mathrm{Cl}^{-}$was

313 positively correlated with $\mathrm{HCO}_{3}{ }^{-}+\mathrm{SO}_{4}{ }^{2-}-\mathrm{Ca}-\mathrm{Mg}$, as shown in Fig. 4(e), revealing that the cation

314 exchange process significantly affects groundwater hydrochemistry. Thus, the Chlor-alkali index

315 (CAI) calculated by Eqs. (14-15) is used to determine the cation exchange patterns.

$316 \mathrm{CAI}-1=\frac{\mathrm{Cl}^{-}-(\mathrm{Na}+\mathrm{K})}{\mathrm{Cl}^{-}}$

$317 \mathrm{CAI}-2=\frac{\mathrm{Cl}^{-}-(\mathrm{Na}+\mathrm{K})}{\mathrm{HCO}_{3}^{-}+\mathrm{SO}_{4}^{2-}+\mathrm{CO}_{3}^{2-}+\mathrm{NO}_{3}^{-}}$

318 Based on Fig. 4(f), the CAI-1 and CAI-2 values of most groundwater samples in the study

319 area were less than 0 , suggesting that $\mathrm{Na}$ on the surface of clay minerals replaces $\mathrm{Ca}$ in

320 groundwater. In the west part of the study area, there was a large amount of $\mathrm{Ca}$ in the 
321 groundwater due to carbonate dissolution. Meanwhile, the aquifer sediments near the shoreline

322 contained a lot of $\mathrm{Na}$ because of seawater intrusion. $\mathrm{Na}$ in sediment substituted $\mathrm{Ca}$ in

323 groundwater during groundwater runoff, resulting in the gradual decrease of Ca concentration

324 along the flow direction. This is also the reason for the distribution of $\mathrm{TH}$ value which was high

325 in the west and low in the east (see Fig. 2(b))

326 The sources of trace elements in shallow groundwater can also be obtained by further

327 analyzing the correlations between different ions in the groundwater. In Table S3, Sr showed a

328 significant positive correlation with both $\mathrm{Ca}$ and $\mathrm{Mg}(\mathrm{r}=0.556$ and 0.586 , respectively, $\mathrm{p}<$

$3290.01)$, and its correlation with $\mathrm{HCO}_{3}{ }^{-}(\mathrm{r}=0.522, \mathrm{p}<0.01)$ was greater than that with $\mathrm{SO}_{4}{ }^{2-}(\mathrm{r}=$

$3300.393, \mathrm{p}<0.01$ ), indicating that strontianite dissolution contributes more to Sr concentration than

331 the dissolution of celestite. Also, a significant positive correlation between $\mathrm{Na}, \mathrm{Br}^{-}$and $\mathrm{B}$ could

332 be found in Table S3, suggesting that $\mathrm{Br}^{-}$and $\mathrm{B}$ are marine origin. $\mathrm{F}^{-}$exhibited a remarkable

333 negative correlation with $\mathrm{Ca}(\mathrm{r}=-0.692, \mathrm{p}<0.01)$, which demonstrates that fluorite releases $\mathrm{F}^{-}$in

$334 \mathrm{Na}-\mathrm{HCO}_{3}$ type groundwater during the process of forming calcite precipitates (Jia et al. 2019).

335 Meanwhile, $\mathrm{F}^{-}$was significantly positively correlated with $\mathrm{Na}(\mathrm{r}=0.425, \mathrm{p}<0.01)$, because the

336 decline of $\mathrm{Ca}$ concentration in groundwater, which is due to the cation exchange adsorption

337 between $\mathrm{Na}$ in the sediment and $\mathrm{Ca}$ in the groundwater, accelerated the fluorite dissolution (Liu

338 et al. 2021a). Fe had a significant positive correlation with $\mathrm{Mn}(\mathrm{r}=0.748, \mathrm{p}<0.01)$, but its

339 correlation with $\mathrm{SO}_{4}{ }^{2-}$ was not significant, which is due to the existence of oolitic Fe-Mn nodules 
340 in the aquifer. Thus, Fe and Mn mainly emanate from the weathering of these Fe-Mn nodules. In

341 addition, As was also positively correlated with Fe and Mn with correlation coefficients of 0.416

342 and $0.377(\mathrm{p}<0.01)$, respectively. The redox of Fe and Mn strongly influences the geochemical

343 cycling of As in groundwater (Saha and Rahman 2020). In the oxygenated environment, As is

344 adsorbed by the oxides and hydroxides of Fe and $\mathrm{Mn}$; while in the anaerobic environment, the

345 reduction of oxides of Fe and $\mathrm{Mn}$ decreases the adsorption sites for As on their surface; at the

346 same time, the $\mathrm{As}(\mathrm{V})$ is reduced to $\mathrm{As}(\mathrm{III})$ which has weak adsorption, thus promoting the

347 release of As from sediment to groundwater (Duan et al. 2017). Besides, As was apparently

348 negatively correlated with $\mathrm{NO}_{3}{ }^{-}(\mathrm{r}=-0.336, \mathrm{p}<0.01)$. It has been proposed that the reduction of

$349 \mathrm{NO}_{3}{ }^{-}$occurs in the presence of denitrifying bacteria; this process can provide $\mathrm{As}(\mathrm{V})$ with enough

350 electrons, accelerating the reduction of $\mathrm{As}(\mathrm{V})$ to $\mathrm{As}(\mathrm{III})$; thus, more As ions are released into the

351 groundwater (Xie et al. 2018). Ni did not exhibit any significant correlations with other trace

352 elements. Ni is an important raw material for industrial activities, and its improper use can lead

353 to groundwater pollution. The Fig. 3(h) showed the central and southeastern parts of the study

354 area had relatively high Ni levels. Because there are a lot of industrial parks located in these

355 regions and the wastewater discharged from industrial activities may elevate level of $\mathrm{Ni}$.

3573.3 Shallow groundwater quality assessment in the study area

358 3.3.1 For irrigation purposes 
360 groundwater is an important water source for agricultural irrigation. The $\mathrm{Na} \%$ ranged from

$36112.30 \%$ to $81.06 \%$, with an average value of $38.05 \%$; and the SAR varied from 0.53 to 11.96

362 with a mean value of 2.70. According to the Wilcox diagram (see Fig. 5(a)), most groundwater

363 samples were in the good to permissible section $(68.85 \%$ ), while $22.95 \%$ of the samples were in

364 the doubtful to unsuitable section and $4.92 \%$ of the samples belonged to the unsuitable section,

365 indicating that the groundwater is unsuitable for irrigation in some regions with high Na content.

366 In addition, based on the classification proposed by the U.S. Salinity Laboratory (USSL) (see

367 Fig. 5(b)), the majority of the groundwater samples were located in the C3S1 zone (72.13\%). In

368 comparison, $27.87 \%$ of the samples were situated in the C4S1, C4S2, C4S3, and C3S2 zones,

369 suggesting that nearly $30 \%$ of the shallow groundwater is not suitable for irrigation in the study

370 area. In summary, the $\mathrm{Na} \%$ and $\mathrm{SAR}$ values reveal that shallow groundwater in regions with

371 severe seawater intrusion (e.g., Nantong and Haimeng cities) is unsuitable for irrigation. The

372 people in these places should pay special attention to it in agricultural production.

374 3.3.2 For drinking purposes

375 Fig. S6 demonstrated $E f S$ values, the ratios of measured values of hydrochemical indicators

376 to their corresponding upper limits in the national drinking water standard (GB5749-2006).

377 Among them, the indicators with $E f S>1$ were TDS, TH, $\mathrm{Na}, \mathrm{Cl}^{-}, \mathrm{SO}_{4}{ }^{2-}, \mathrm{NO}_{3}{ }^{-}, \mathrm{F}^{-}, \mathrm{Al}, \mathrm{Mn}, \mathrm{Fe}, \mathrm{Ni}$, 
378 As, B, Cr and Se, with the exceeding rates of $32.79 \%, 42.62 \%, 18.3 \%, 8.20 \%, 4.92 \%, 8.20 \%$,

$3791.64 \%, 1.64 \%, 8.20 \%, 3.28 \%, 3.28 \%, 26.23 \%, 13.11 \%, 6.56 \%$ and $1.64 \%$, respectively. Se and

380 As had the highest exceedance levels, with maximum Efs values of 13.57 and 7.78, respectively.

381 There were only $27.87 \%$ of water samples whose indicators all met the standard (GB5749-2006).

382 In addition, WQI values of shallow groundwater varied from 17.42 to 140.20 , with an average

383 value of 52.02. According to their WQI values, the percentage of groundwater with excellent,

384 good, medium, and poor quality were $9.8 \%, 52.5 \%, 31.1 \%$, and $6.6 \%$, respectively. Thus, most

385 shallow groundwater can be utilized for drinking in the study area. Fig. 6(a) presented the spatial

386 distribution of WQI values in the study area. It could be found that the groundwater samples with

387 excellent and good quality were from the eastern and northern parts of the study area. Besides,

388 groundwater samples with medium and poor quality were sporadically distributed in the central

389 part of the study area like Nantong city, and in the southeastern part of the study area like Qidong

390 city.

391 The HI values of shallow groundwater in the study area were in the range of 0.264-9.555,

392 with a mean of 1.795 . The percentage of groundwater samples with $\mathrm{HI}>1$ in the study area was

$39344.3 \%$. Overall, groundwater in some regions may pose a significant non-carcinogenic risk to the

394 health of local residents. Fig. 6(b) showed that the groundwater in the southwestern part of

395 Rugao city, Nantong city, and the northern and southeastern coastal regions of Qidong city had

$396 \mathrm{HI}>1$. Except for Rugao city, the spatial distribution of HI was consistent with that of As (see 
Fig. 3(f)). Thus, As level is the main factor affecting the HI values.

Fig. 7 displayed the non-carcinogenic risks of different trace elements obtained by oral

399 intake and dermal absorption in children. The non-carcinogenic risk of each trace element

400 obtained through dermal absorption was 2 orders of magnitude less than that obtained through

401 the oral intake, and $\mathrm{HQ}_{\text {dermal }}$ was far less than 1, indicating that oral intake is the main health risk

402 exposure pathway and the non-carcinogenic health risk through dermal absorption is negligible.

403 With the exception of As, the maximum HQoral value of each trace element was less than 1 . The

404 mean and maximum values of $\mathrm{HQ}_{\text {oral }}$ for As were 1.371 and 9.284, showing significant health

405 risks. The average $\mathrm{HI}$ value of each trace element was in the order of As (1.374) $>\mathrm{Li}(0.217)>\mathrm{B}$

$406(0.052)>\operatorname{Sr}(0.030)>\operatorname{Se}(0.020)>\mathrm{Cr}(0.019)>\mathrm{Tl}(0.019)>\mathrm{Ba}(0.013)>\mathrm{Sb}(0.011)>$ others. It

407 is worth noting that the maximum $E f S$ value of Se was 13.57 , and its maximum HI value was

408 0.973, which is close to the threshold value of the non-carcinogenic health risk. The HI values of

$409 \mathrm{Al}, \mathrm{Mn}, \mathrm{Fe}, \mathrm{Ni}$, and B, which exceeded the national drinking water standard, were low, with

410 maximum values of $0.008,0.096,0.035,0.037$, and 0.180 , respectively. These trace elements

411 have no significant non-carcinogenic health risks.

412 In Fig. S7, As in shallow groundwater made the greatest contribution to the HI calculations,

413 with a mean value of $54.1 \%$ and a maximum value of $97.4 \%$; followed by $\mathrm{Li}$, with a mean value

414 of $24.9 \%$ and a maximum value of $74.2 \%$; the average contribution of the remaining elements to

415 total HI was less than $10 \%$. In general, the contribution (mean value) of each element to HI in 
416 shallow groundwater in the study area has the following order: As $(54.1 \%)>\mathrm{Li}(24.9 \%)>\mathrm{B}$

$417(5.0 \%)>\mathrm{Tl}(4.0 \%)>\mathrm{Sr}(3.5 \%)>\mathrm{Cr}(2.2 \%)>\mathrm{Sb}(1.5 \%)>\mathrm{Ba}(1.4 \%)>\mathrm{Co}(1.0 \%)>$ others.

418 Long-term ingestion of high As groundwater will lead to serious diseases such as skin,

419 hematological, and renal diseases (Wu et al. 2020). As should be the focus of attention in

420 drinking water risk management in the study area.

421 As mentioned above, the results of WQI and HI assessments are broadly consistent. For

422 example, in the north part of the study area, the groundwater had good quality with low WQI and

423 HI values; in contrast, the groundwater quality in the middle and southeast parts was poor with

424 high WQI and HI values. However, some areas had opposite WQI and HI values; for instance,

425 the WQI value was low but the HI value was high in southwest Rugao city. This is because WQI

426 chooses the restrictive indicators such as TDS, TH, pH, etc., in the national drinking water

427 standards for water quality evaluation. However, the HI assessment includes some trace elements

428 such as $\mathrm{Sr}$ and $\mathrm{Li}$, which are not restricted in national drinking water standards. Therefore,

429 combining the results from these two assessments provides a more comprehensive understanding

430 of the effects of shallow groundwater quality on health. Taken together, the shallow groundwater

431 in some regions may pose significant health risks to local residents. For example, the shallow

432 groundwater in southwest Rugao city, Nantong city, and parts of Qidong city was no longer

433 suitable as drinking water due to the high As concentration which was a severe threat to the

434 health of local residents. High arsenic groundwater is a current environmental and health 
435 problem worldwide (Podgorski and Berg 2020). Numerous studies on the causes and health risks

436 of high arsenic groundwater have been conducted in the Hetao plain and Jianghan plain in China,

437 while the investigations in the Yangtze River Delta have not been reported (Mao et al. 2018;

438 Zheng et al. 2020). Unlike Hetao plain and Jianghan plain, the Yangtze River Delta is one of the

439 most densely populated areas in China. Thus the health risks associated with high arsenic

440 groundwater require more attention.

441 Since shallow groundwater is an important water source for irrigation, heavy metals in the

442 water can be enriched through crops. However, in this study, the health risk assessments did not

443 consider the elements from food, resulting in an underestimation of health risk. In addition, the

444 relative sparsity of sampling points could lead to the uncertainty of the spatial distribution of

445 groundwater quality. More detailed research should be carried out in regions with severe

446 seawater intrusion and high As concentrations in the future.

\section{4. Conclusions}

449 In this study, the shallow groundwater in the coastal plain of Yangtze River Delta was

450 sampled and analyzed. On this basis, groundwater quality was evaluated using methods such as

451 WQI and HI. The results showed that the shallow groundwater was slightly alkaline in the study

452 area. The mean values of TDS and TH were $930.74 \mathrm{mg} / \mathrm{L}$ and $436.20 \mathrm{mg} / \mathrm{L}$, indicating that the

453 groundwater was moderately hard, hard, and very hard. $\mathrm{Na}$ and $\mathrm{HCO}_{3}{ }^{-}$had the highest 
454 concentrations in the shallow groundwater. The percentages of groundwater samples with $455 \mathrm{Ca}+\mathrm{Mg}-\mathrm{HCO}_{3}$ type and $\mathrm{Ca} / \mathrm{Na}-\mathrm{HCO}_{3}$ type were $44.3 \%$ and $47.5 \%$, respectively. $\mathrm{Sr}, \mathrm{Br}, \mathrm{F}$ and $\mathrm{B}$ 456 were the major trace elements with mean values of $0.4975 \mathrm{mg} / \mathrm{L}, 0.3729 \mathrm{mg} /, 0.3470 \mathrm{mg} / \mathrm{L}$ and $457 \quad 0.2888 \mathrm{mg} / \mathrm{L}$, respectively. Meanwhile, As had a relatively high concentration in shallow 458 groundwater (its average value was $0.0115 \mathrm{mg} / \mathrm{L}$ ). Factors like rock weathering (silicate), cation 459 exchange, seawater intrusion, and industrial and agricultural activities played an important role 460 in the chemical composition of shallow groundwater in the Yangtze River Delta plain. The 461 massive exploitation of shallow groundwater has caused the most severe seawater intrusion in 462 Nantong city. The trace element like $\mathrm{Br}^{-}$and $\mathrm{B}$ in shallow groundwater had a marine origin. $\mathrm{Fe}$ 463 and Mn mainly derived from the weathering of Fe-Mn nodules in the sediments; and As was 464 strongly affected by the redox of $\mathrm{Fe}, \mathrm{Mn}$, and $\mathrm{NO}_{3}^{-}$. In addition, wastewater discharged from 465 industrial activities has contributed to the increased concentration of heavy metals in 466 groundwater. According to the water quality assessment, shallow groundwater in some regions 467 was unsuitable for irrigation. At the same time, TDS, $\mathrm{TH}, \mathrm{Na}, \mathrm{Cl}^{-}, \mathrm{SO}_{4}{ }^{2-}, \mathrm{NO}_{3}^{-}, \mathrm{F}^{-}, \mathrm{Al}, \mathrm{Mn}, \mathrm{Fe}$, $468 \mathrm{Ni}, \mathrm{As}, \mathrm{B}, \mathrm{Cr}$ and $\mathrm{Se}$ in some groundwater samples exceeded their corresponding upper limits in 469 the national drinking water standard. There were only $27.87 \%$ of the groundwater samples whose 470 indicators were in line with the national drinking water standard. According to the classification 471 of WQI values, excellent, good, medium, poor groundwater samples accounted for $9.8 \%, 52.5 \%$, $47231.1 \%$, and $6.6 \%$, respectively. The analysis of health risk showed that $44.3 \%$ of the water 
473 samples had significant health risks, and As played the most important role in health risk, with a

474 mean contribution of $54.1 \%$ to the total HI; therefore, As should become the focus in drinking

475 water management in the study area. The shallow groundwater quality in the Yangtze River

476 Delta, especially the concentrations of trace elements and their health risk assessment, has been

477 neglected for a long time. It is necessary to conduct long-term monitoring of As contamination in

478 the Yangtze River Delta and to take measures to prevent and control groundwater contamination.

479 In the meantime, new high-quality water sources should be sought for the regions, such as

480 Nantong city, where seawater intrusion is serious; and shallow groundwater extraction should be

481 reduced to maintain sustainable groundwater resource management.

482

483 Ethics approval and consent to participate

$484 \quad$ Not applicable.

485

486 Consent for publication

$487 \quad$ Not applicable.

488

489 Author Contributions

490 Taotao Lu: Conceptualization, Methodology, Investigation, Writing- Original draft

491 preparation; Runzhe Li: Methodology, Investigation; Aira Sacha Nadine Ferrer: Resources; 
492 Shuang Xiong: Software, Investigation; Pengfei Zou: Supervision, Funding acquisition; Hao 493 Peng: Formal analysis, Writing- Original draft preparation, Writing- Reviewing and Editing. 494

\section{Funding}

496 This project was supported by New Era Health Industry (Group) Co. Ltd.

497 (ZAT2019X01002) and the China Scholarship Council (201708420145).

498

499 Conpeting Interests

500 The authors declare that they have no known competing financial interests or personal

501 relationships that could have appeared to influence the work reported in this paper.

502

503 Availability of data and materials

504 Supplementary Material data to this article can be found in the online version of this article.

505

506 References

507 Appelo CAJ, Postma D (2005) Geochemistry, Groundwater and Pollution, second ed. A.A.

$508 \quad$ Balkema Publishers, Leiden

509 Argamasilla M, Barberá J, Andreo B (2017) Factors controlling groundwater salinization and

510 hydrogeochemical processes in coastal aquifers from southern Spain. Sci Total Environ 
$511 \quad 580: 50-68$

512 Cao T, Han D, Song X, Trolle D (2020) Subsurface hydrological processes and groundwater

513 residence time in a coastal alluvium aquifer: Evidence from environmental tracers $(\delta 18 \mathrm{O}$,

$514 \quad \delta 2 \mathrm{H}, \mathrm{CFCs}, 3 \mathrm{H})$ combined with hydrochemistry. Sci Total Environ 743:140684

515 Chen L, Ma T, Wang Y, Zheng J (2020) Health risks associated with multiple metal (loid) s in

516 groundwater: A case study at Hetao Plain, northern China. Environ Pollut 263:114562

517 Duan Y, Gan Y, Wang Y, Liu C, Yu K, Deng Y, Zhao K, Dong C (2017) Arsenic speciation in

518 aquifer sediment under varying groundwater regime and redox conditions at Jianghan Plain

519 of Central China. Sci Total Environ 607:992-1000

520 Gao Y, Qian H, Ren W, Wang H, Liu F, Yang F (2020) Hydrogeochemical characterization and

521 quality assessment of groundwater based on integrated-weight water quality index in a

522 concentrated urban area. J Clean Prod 260:121006

523 Gibbs RJ (1970) Mechanisms controlling world water chemistry. Science 170:1088-1090

524 Han D, Post VE, Song X (2015) Groundwater salinization processes and reversibility of seawater

525 intrusion in coastal carbonate aquifers. J Hydrol 531:1067-1080

526 Hao C, Zhang W, Gui H (2020) Hydrogeochemistry characteristic contrasts between low-and

527 high-antimony in shallow drinkable groundwater at the largest antimony mine in Hunan

$528 \quad$ province, China. Appl Geochem 117:104584

529 Hou Q, Zhang Q, Huang G, Liu C, Zhang Y (2020) Elevated manganese concentrations in 
shallow groundwater of various aquifers in a rapidly urbanized delta, south China. Sci Total Environ 701:134777

Islam ARMT, Al Mamun A, Rahman MM, Zahid A (2020) Simultaneous comparison of modified-integrated water quality and entropy weighted indices: implication for safe drinking water in the coastal region of Bangladesh. Ecol Indic 113:106229

Jia H, Qian H, Qu W, Zheng L, Feng W, Ren W (2019) Fluoride occurrence and human health risk in drinking water wells from southern edge of Chinese Loess Plateau. Int J Environ Res Public Health 16:1683

Li Q, Zhang Y, Chen W, Yu S (2018) The integrated impacts of natural processes and human activities on groundwater salinization in the coastal aquifers of Beihai, southern China.

541 Li X, Tang C, Cao Y, Li D (2020) A multiple isotope (H, O, N, C and S) approach to elucidate Hydrogeol J 26:1513-1526

544 Lima IQ, Ramos OR, Munoz MO, Aguirre JQ, Duwig C, Maity JP, Sracek O, Bhattacharya P

545 (2020) Spatial dependency of arsenic, antimony, boron and other trace elements in the

546 shallow groundwater systems of the Lower Katari Basin, Bolivian Altiplano. Sci Total

$547 \quad$ Environ 719:137505

548 Liu J, Peng Y, Li C, Gao Z, Chen S (2021a) A characterization of groundwater fluoride, 
influencing factors and risk to human health in the southwest plain of Shandong Province, North China. Ecotoxicol Environ Saf 207:111512

551 Liu J, Peng Y, Li C, Gao Z, Chen S (2021b) Characterization of the hydrochemistry of water resources of the Weibei Plain, Northern China, as well as an assessment of the risk of high

554 Liu J, Peng Y, Li C, Gao Z, Chen S (2021c) An investigation into the hydrochemistry, quality and groundwater nitrate levels to human health. Environ Pollut 268:115947

Liu, X., Wang, X., Zhang, L., Fan, W., Yang, C., Li, E., Wang, Z., 2021d. Impact of land use on risk to human health of groundwater in the central region of Shandong Province, North

China. J Clean Prod 282:125416 shallow groundwater quality characteristics associated with human health risks in a typical

agricultural area in Central China. Environ. Sci. Pollut. Res. 28, 1712-1724

Long, J., Luo, K., 2020. Elements in surface and well water from the central North China Plain: enrichment patterns, origins, and health risk assessment. Environ. Pollut. 258, 113725

Long X, Liu F, Zhou X, Pi J, Yin W, Li F, Huang S, Ma F (2021) Estimation of spatial distribution and health risk by arsenic and heavy metals in shallow groundwater around Dongting Lake plain using GIS mapping. Chemosphere 269:128698

Ma Q, Luo Z, Howard KW, Wang Q (2018) Evaluation of optimal aquifer yield in Nantong City, China, under land subsidence constraints. Q J Eng Geol Hydrogeol 51:124-137

Mao C, Tan H, Song Y, Rao W (2020) Evolution of groundwater chemistry in coastal aquifers of 
the Jiangsu, east China: Insights from a multi-isotope $(\delta 2 \mathrm{H}, \delta 18 \mathrm{O}, 87 \mathrm{Sr} / 86 \mathrm{Sr}$, and $\delta 11 \mathrm{~B})$ approach. J Contam Hydrol 235:103730

Mao R, Guo H, Xiu W, Yang Y, Huang X, Zhou Y, Li X, Jin J (2018) Characteristics and compound-specific carbon isotope compositions of sedimentary lipids in high arsenic aquifers in the Hetao basin, Inner Mongolia. Environ Pollut 241:85-95

573 Mountadar S, Younsi A, Hayani A, Siniti M, Tahiri S (2018) Groundwater salinization process in 574 the coastal aquifer sidi abed-ouled ghanem (province of el Jadida, Morocco). J African

Najib S, Fadili A, Mehdi K, Riss J, Makan A, Guessir H (2016) Salinization process and coastal

Narayanamoorthy S, Annapoorani V, Kang D, Baleanu D, Jeon J, Kureethara JV, Ramya L groundwater quality in Chaouia, Morocco. J African Earth Sci 115:17-31 longevity area, China: Hydrogeochemical characteristics, enrichment patterns and health assessments. Ecotoxicol Environ Saf 218:112279

586 Podgorski J, Berg M (2020) Global threat of arsenic in groundwater. Science 368:845-850. 
587 Saha N, Rahman MS (2020) Groundwater hydrogeochemistry and probabilistic health risk assessment through exposure to arsenic-contaminated groundwater of Meghna floodplain, central-east Bangladesh. Ecotoxicol Environ Saf 206:111349

Samsudin AR, Haryono A, Hamzah U, Rafek A (2008) Salinity mapping of coastal groundwater aquifers using hydrogeochemical and geophysical methods: a case study from north Kelantan, Malaysia. Environ Geol 55:1737-1743

593 Selinus O, Alloway B, Centeno JA, Finkelman RB, Fuge R, Lindh U, Smedley P (2016)

$594 \quad$ Essentials of medical geology. Springer, Dordrecht

595 Wang L, Yin Z, Jing C (2020) Metagenomic insights into microbial arsenic metabolism in shallow groundwater of Datong basin, China. Chemosphere 245:125603

Wu C, Fang C, Wu X, Zhu G (2020) Health-Risk Assessment of Arsenic and Groundwater Quality Classification Using Random Forest in the Yanchi Region of Northwest China.

600 Wu C, Luo Y, Gui T, Yan S (2014) Characteristics and potential health hazards of organochlorine 601 Expos Health 12:761-774

$603 \mathrm{Wu}$ J, Sun Z (2016) Evaluation of shallow groundwater contamination and associated human 604 health risk in an alluvial plain impacted by agricultural and industrial activities, mid-west 605 China. Expos Health 8:311-329 
606 Xie Z, Wang J, Wei X, Li F, Chen M, Wang J, Gao B (2018) Interactions between arsenic

607 adsorption/desorption and indigenous bacterial activity in shallow high arsenic aquifer

608 sediments from the Jianghan Plain, Central China. Sci Total Environ 644:382-388

609 Zhang Q, Qian H, Xu P, Hou K, Yang F (2021) Groundwater quality assessment using a new

610 integrated-weight water quality index (IWQI) and driver analysis in the Jiaokou Irrigation

611 District, China. Ecotoxicol Environ Saf 212:111992

612 Zhang Q, Xu P, Qian H (2020) Groundwater quality assessment using improved water quality

613 index (WQI) and human health risk (HHR) evaluation in a semi-arid region of northwest

614 China. Expos Health 12:487-500

615 Zhao Q, Su X, Kang B, Zhang Y, Wu X, Liu M (2017) A hydrogeochemistry and multi-isotope

616 (Sr, O, H, and C) study of groundwater salinity origin and hydrogeochemcial processes in

617 the shallow confined aquifer of northern Yangtze River downstream coastal plain, China.

618 Appl Geochem 86:49-58

619 Zheng T, Deng Y, Wang Y, Jiang H, Xie X, Gan Y (2020) Microbial sulfate reduction facilitates

620 seasonal variation of arsenic concentration in groundwater of Jianghan Plain, Central China.

$621 \quad$ Sci Total Environ 735:139327

622 Zhi C, Cao W, Zhang Z, Li Z, Ren Y (2021) Hydrogeochemical characteristics and processes of

623 shallow groundwater in the Yellow River Delta, China. Water 13:534

624 
625 Table 1. Chemical composition and their statistical characteristics in the shallow groundwater in the study area

\begin{tabular}{|c|c|c|c|c|c|c|c|c|c|}
\hline \multirow{2}{*}{ Unit } & \multirow{2}{*}{ Project } & \multirow{2}{*}{$\begin{array}{c}\text { Detection } \\
\text { Limit }\end{array}$} & \multirow{2}{*}{$\begin{array}{c}\text { Minimum } \\
\text { value }\end{array}$} & \multirow{2}{*}{$\begin{array}{c}\text { Maximum } \\
\text { value }\end{array}$} & \multirow{2}{*}{$\begin{array}{c}\text { Average } \\
\text { value }\end{array}$} & \multirow{2}{*}{ Median } & \multirow{2}{*}{$\begin{array}{l}\text { Standard } \\
\text { deviation }\end{array}$} & \multicolumn{2}{|c|}{ Shapiro-Wilk Test } \\
\hline & & & & & & & & H-value & Sig \\
\hline-- & $\mathrm{pH}$ & -- & 6.90 & 7.90 & 7.31 & 7.30 & 0.23 & 0.967 & 0.104 \\
\hline $\mathrm{mg} / \mathrm{L}$ & TDS & -- & 411.45 & 2361.77 & 930.74 & 841.68 & 370.26 & 0.907 & 0 \\
\hline $\mathrm{mg} / \mathrm{L}$ & $\mathrm{TH}$ & -- & 181.63 & 897.74 & 436.20 & 418.98 & 144.02 & 0.959 & 0.041 \\
\hline $\mathrm{mg} / \mathrm{L}$ & $\mathrm{Na}$ & 0.002 & 24.00 & 482.79 & 124.08 & 99.90 & 92.52 & 0.828 & 0 \\
\hline $\mathrm{mg} / \mathrm{L}$ & $\mathrm{Mg}$ & 0.01 & 20.11 & 106.15 & 52.21 & 48.96 & 19.73 & 0.961 & 0.047 \\
\hline $\mathrm{mg} / \mathrm{L}$ & $\mathrm{K}$ & 0.001 & 2.61 & 221.00 & 22.80 & 11.93 & 31.75 & 0.517 & 0 \\
\hline $\mathrm{mg} / \mathrm{L}$ & $\mathrm{Ca}$ & 0.02 & 22.46 & 277.49 & 87.46 & 81.55 & 45.27 & 0.905 & 0 \\
\hline $\mathrm{mg} / \mathrm{L}$ & $\mathrm{HCO}_{3}^{-}$ & 0.01 & 292.47 & 860.20 & 543.87 & 504.65 & 135.43 & 0.944 & 0.008 \\
\hline $\mathrm{mg} / \mathrm{L}$ & $\mathrm{Cl}^{-}$ & 0.004 & 11.18 & 806.00 & 117.99 & 88.20 & 114.16 & 0.648 & 0 \\
\hline $\mathrm{mg} / \mathrm{L}$ & $\mathrm{NO}_{3}{ }^{-}$ & 0.0006 & 0.03 & 139.77 & 32.29 & 22.90 & 32.34 & 0.854 & 0 \\
\hline $\mathrm{mg} / \mathrm{L}$ & $\mathrm{SO}_{4}^{2-}$ & 0.002 & 6.57 & 271.90 & 96.12 & 87.79 & 63.07 & 0.906 & 0 \\
\hline $\mathrm{mg} / \mathrm{L}$ & $\mathrm{F}^{-}$ & 0.00002 & 0.0240 & 1.0790 & 0.3470 & 0.2977 & 0.2103 & 0.867 & 0 \\
\hline $\mathrm{mg} / \mathrm{L}$ & $\mathrm{Br}^{-}$ & 0.00002 & 0.0000 & 2.6350 & 0.3729 & 0.2598 & 0.4114 & 0.215 & 0 \\
\hline $\mathrm{mg} / \mathrm{L}$ & $\mathrm{Sr}$ & 0.0001 & 0.1814 & 0.9882 & 0.4975 & 0.4532 & 0.1800 & 0.958 & 0.037 \\
\hline $\mathrm{mg} / \mathrm{L}$ & $\mathrm{Al}$ & 0.00004 & 0.0007 & 0.2291 & 0.0526 & 0.0410 & 0.0443 & 0.840 & 0 \\
\hline $\mathrm{mg} / \mathrm{L}$ & $\mathrm{Cr}$ & 0.00005 & 0.0000 & 0.0104 & 0.0014 & 0.0006 & 0.0020 & 0.606 & 0 \\
\hline $\mathrm{mg} / \mathrm{L}$ & $\mathrm{Mn}$ & 0.00002 & 0.0000 & 0.3732 & 0.0204 & 0.0021 & 0.0588 & 0.388 & 0 \\
\hline $\mathrm{mg} / \mathrm{L}$ & $\mathrm{Fe}$ & 0.00006 & 0.0017 & 0.6774 & 0.0484 & 0.0224 & 0.1032 & 0.345 & 0 \\
\hline $\mathrm{mg} / \mathrm{L}$ & $\mathrm{Ni}$ & 0.00002 & 0.0000 & 0.0205 & 0.0014 & 0.0007 & 0.0036 & 0.306 & 0 \\
\hline $\mathrm{mg} / \mathrm{L}$ & $\mathrm{Cu}$ & 0.00002 & 0.0000 & 0.0736 & 0.0030 & 0.0015 & 0.0094 & 0.229 & 0 \\
\hline $\mathrm{mg} / \mathrm{L}$ & $\mathrm{Zn}$ & 0.00004 & 0.0009 & 0.5300 & 0.0339 & 0.0144 & 0.0787 & 0.358 & 0 \\
\hline $\mathrm{mg} / \mathrm{L}$ & As & 0.00002 & 0.0000 & 0.0778 & 0.0115 & 0.0037 & 0.0179 & 0.653 & 0 \\
\hline $\mathrm{mg} / \mathrm{L}$ & $\mathrm{Li}$ & 0.00006 & 0.0021 & 0.0366 & 0.0121 & 0.0121 & 0.0077 & 0.938 & 0.004 \\
\hline $\mathrm{mg} / \mathrm{L}$ & $\mathrm{B}$ & 0.00004 & 0.0285 & 1.0065 & 0.2888 & 0.2030 & 0.21901 & 0.789 & 0 \\
\hline $\mathrm{mg} / \mathrm{L}$ & $\mathrm{Se}$ & 0.00004 & 0.0000 & 0.1357 & 0.0027 & 0.0000 & 0.0173 & 0.184 & 0 \\
\hline $\mathrm{mg} / \mathrm{L}$ & Mo & 0.00002 & 0.0000 & 0.0076 & 0.0011 & 0.0006 & 0.0014 & 0.746 & 0 \\
\hline $\mathrm{mg} / \mathrm{L}$ & $\mathrm{Ba}$ & 0.00002 & 0.0074 & 0.2828 & 0.0685 & 0.0604 & 0.0397 & 0.628 & 0 \\
\hline$\mu \mathrm{g} / \mathrm{L}$ & $\mathrm{Ag}$ & 0.002 & 0.02 & 0.03 & 0.02 & 0.02 & 0.00 & 0.500 & 0 \\
\hline$\mu \mathrm{g} / \mathrm{L}$ & $\mathrm{Cd}$ & 0.004 & 0.00 & 0.06 & 0.03 & 0.03 & 0.02 & 0.837 & 0 \\
\hline$\mu \mathrm{g} / \mathrm{L}$ & Sn & 0.002 & 0.00 & 0.10 & 0.01 & 0.00 & 0.02 & 0.477 & 0 \\
\hline$\mu \mathrm{g} / \mathrm{L}$ & $\mathrm{Sb}$ & 0.002 & 0.00 & 1.70 & 0.10 & 0.07 & 0.22 & 0.331 & 0 \\
\hline$\mu \mathrm{g} / \mathrm{L}$ & W & 0.01 & 0.00 & 1.27 & 0.09 & 0.04 & 0.17 & 0.366 & 0 \\
\hline$\mu \mathrm{g} / \mathrm{L}$ & $\mathrm{Tl}$ & 0.005 & 0.00 & 0.02 & 0.00 & 0.00 & 0.01 & 0.659 & 0 \\
\hline$\mu \mathrm{g} / \mathrm{L}$ & $\mathrm{Pb}$ & 0.002 & 0.00 & 0.92 & 0.04 & 0.01 & 0.14 & 0.286 & 0 \\
\hline$\mu \mathrm{g} / \mathrm{L}$ & $\mathrm{Be}$ & 0.006 & 0.00 & 1.40 & 0.10 & 0.00 & 0.23 & 0.510 & 0 \\
\hline$\mu \mathrm{g} / \mathrm{L}$ & Co & 0.002 & 0.00 & 0.30 & 0.08 & 0.06 & 0.06 & 0.789 & 0 \\
\hline
\end{tabular}

Note: The concentration of $0.0000 \mathrm{mg} / \mathrm{L}$ or $0.00 \mu \mathrm{g} / \mathrm{L}$ means below the detection line. -- represents not applicable 


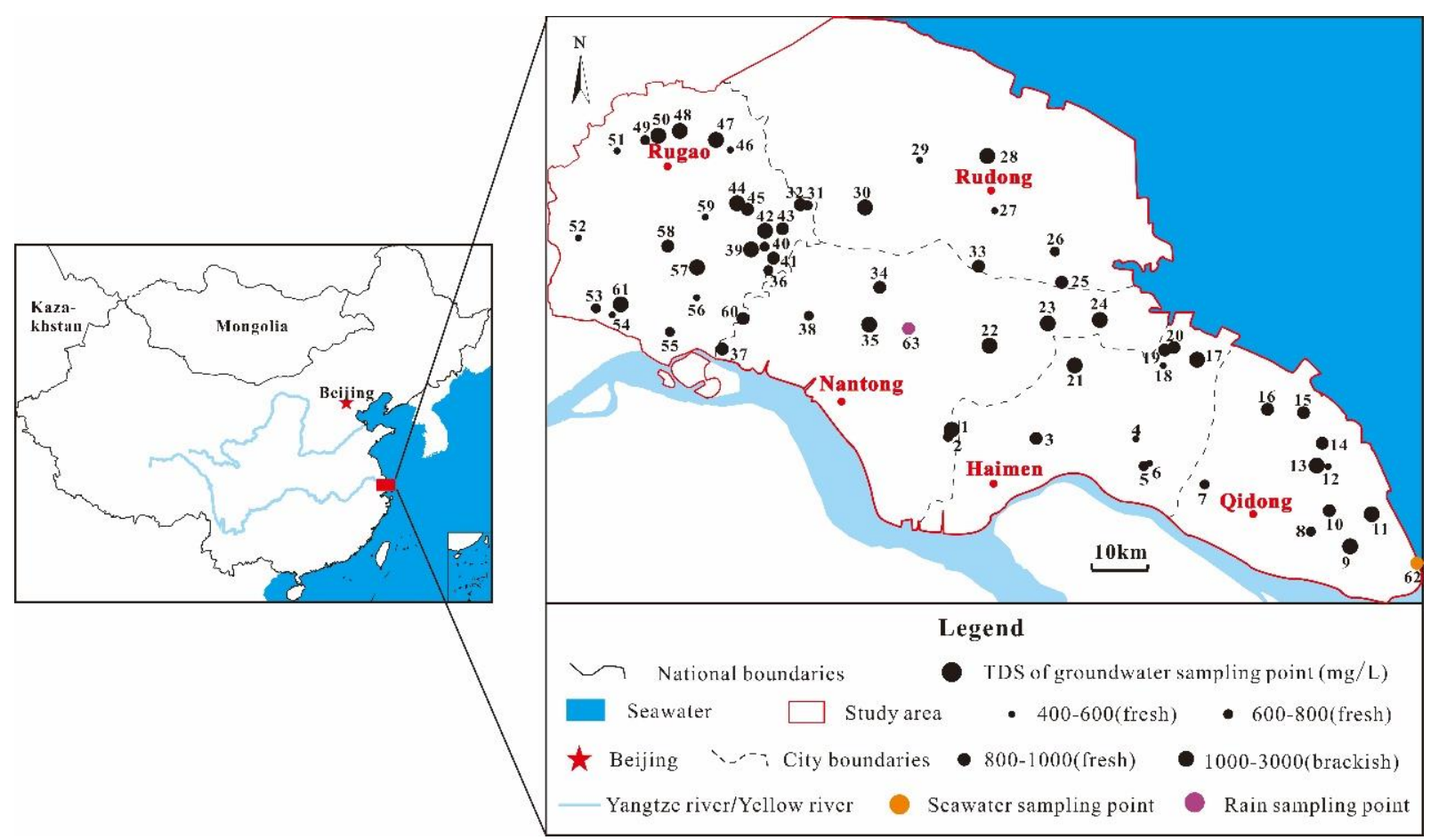

629 Fig. 1 Spatial distribution of groundwater samples in the study area. 

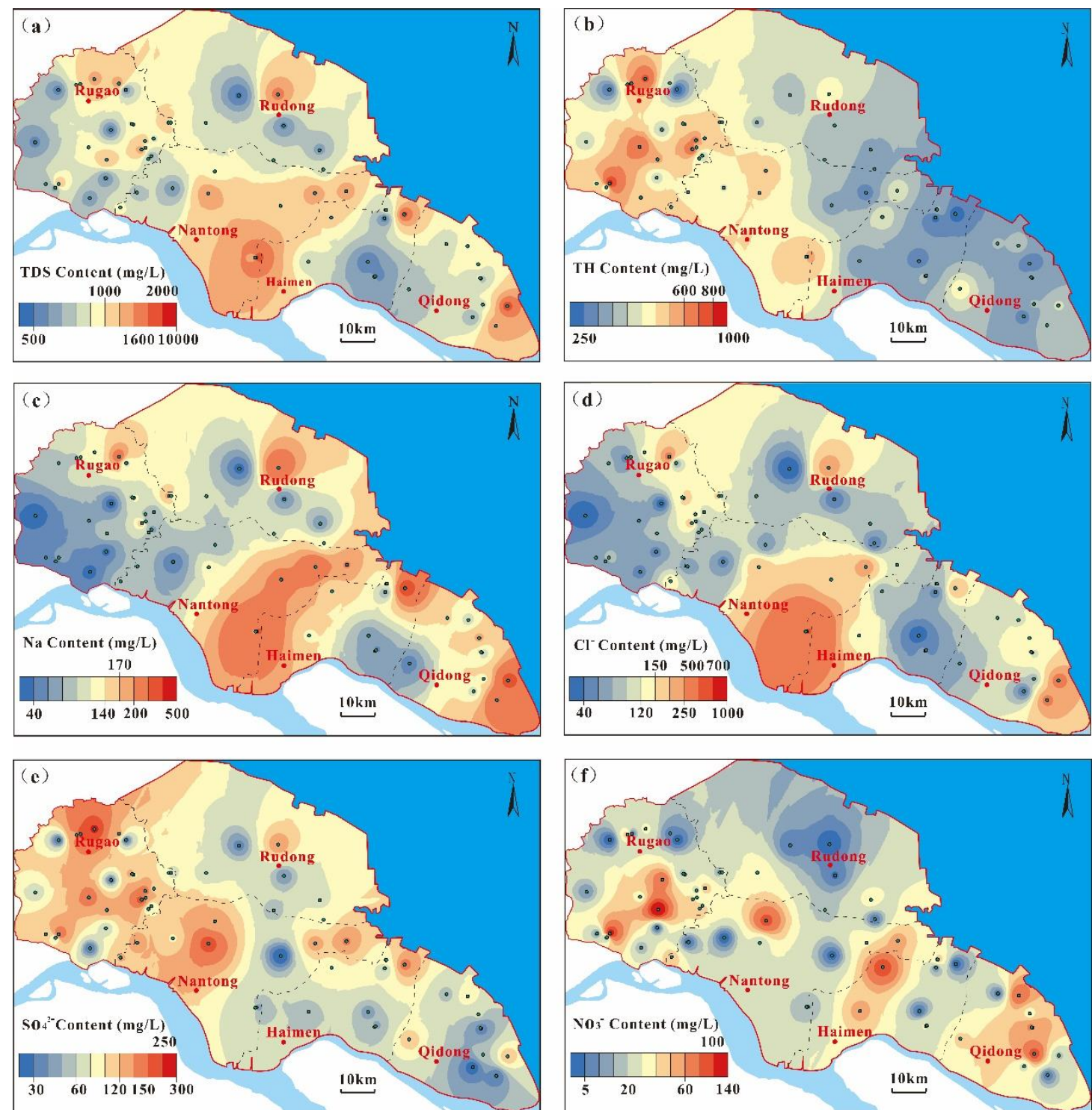

631 Fig. 2 The spatial distributions of the main components in shallow groundwater in the study area:

632 (a) TDS, (b) $\mathrm{TH}$, (c) $\mathrm{Na}$, (d) $\mathrm{Cl}^{-}$, (e) $\mathrm{SO}_{4}{ }^{2-}$ and (f) $\mathrm{NO}_{3}{ }^{-}$. 

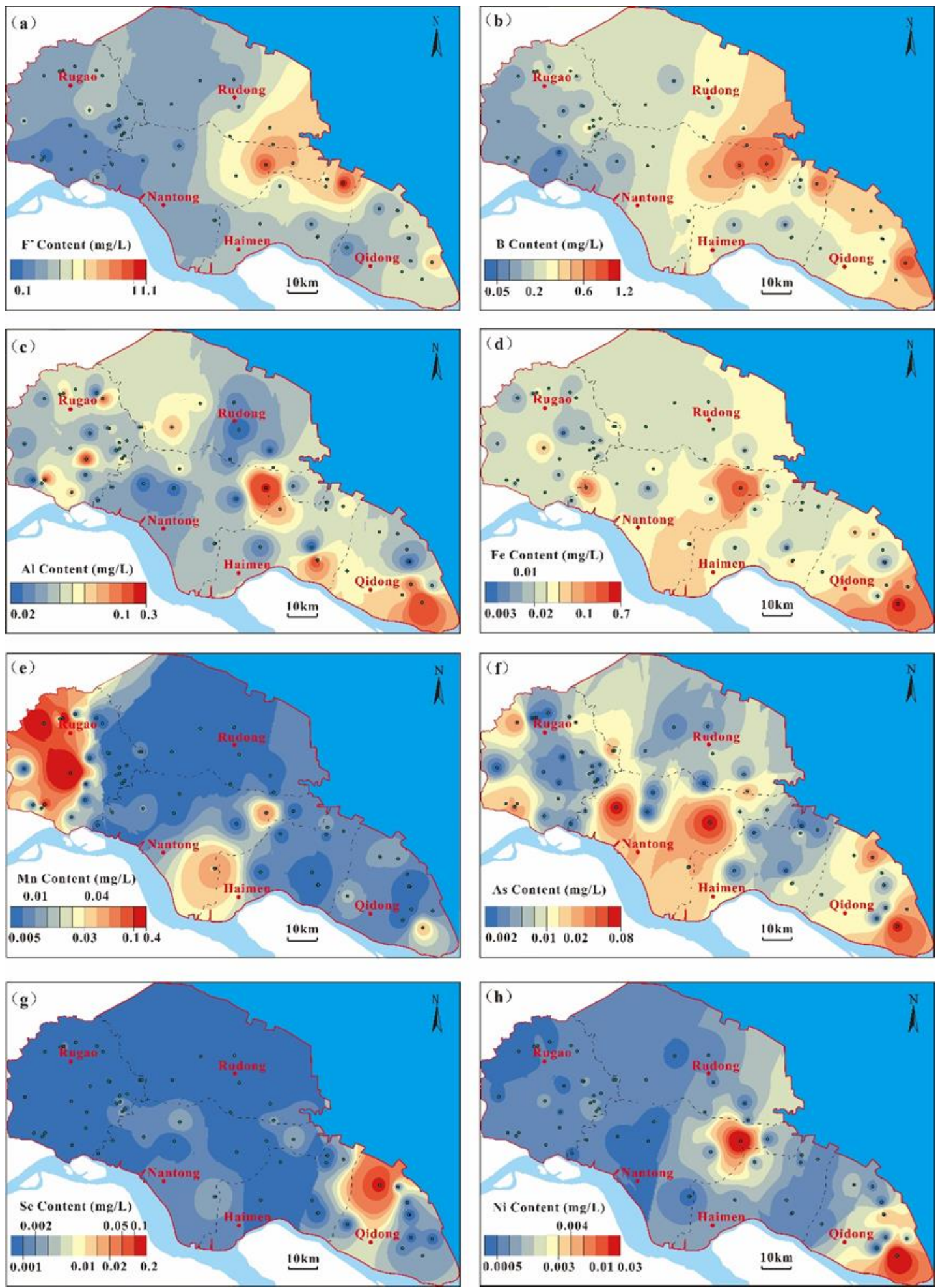

634 Fig. 3 The spatial distributions of the trace elements in shallow groundwater in the study area:

635 (a) F', (b) B, (c) Al, (d) Fe, (e) Mn, (f) As, (g) Se, and (h) Ni. 

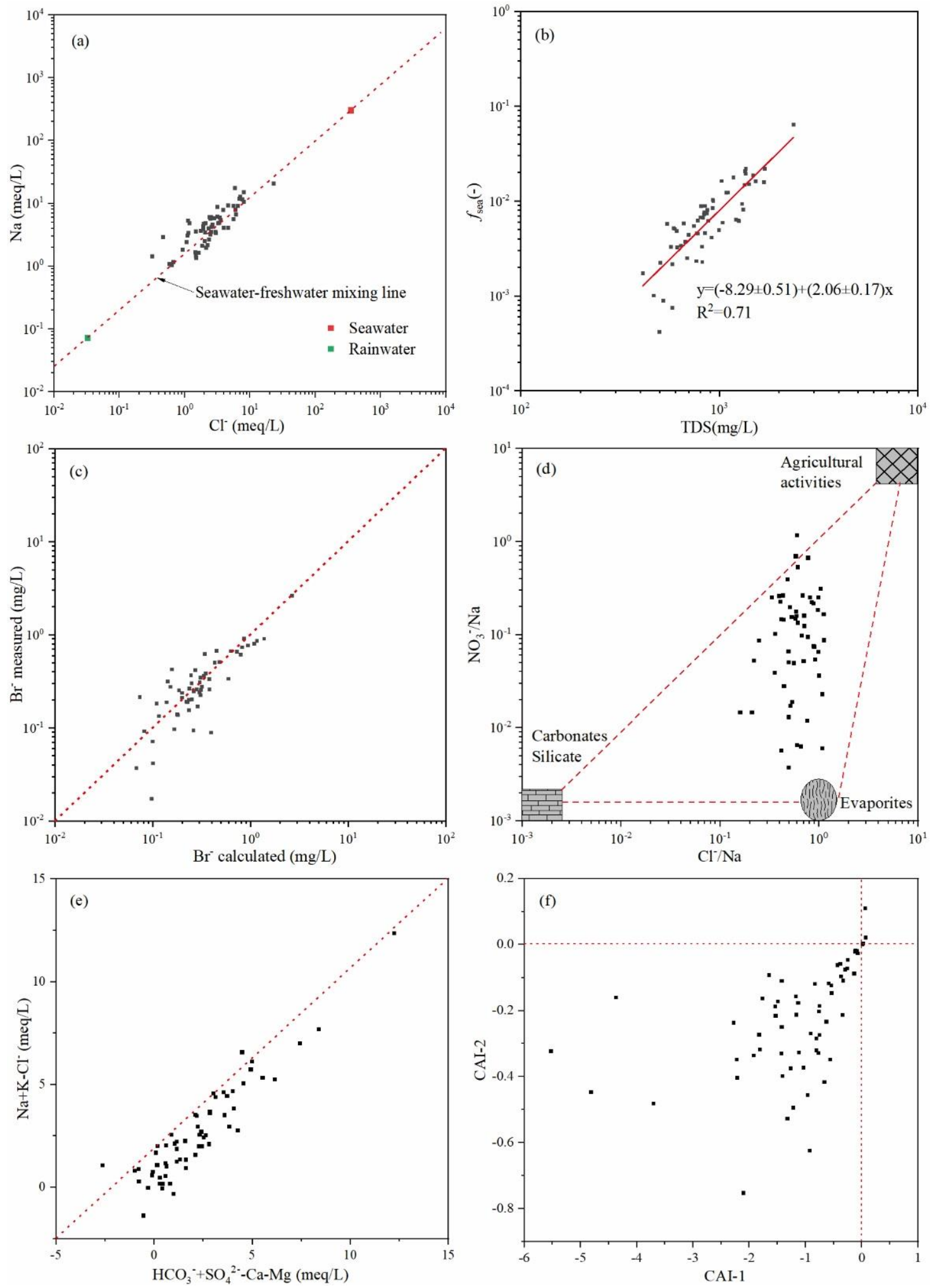

Fig. 4 Ratio graphs of different indicators in shallow groundwater in the study area. 
(a)

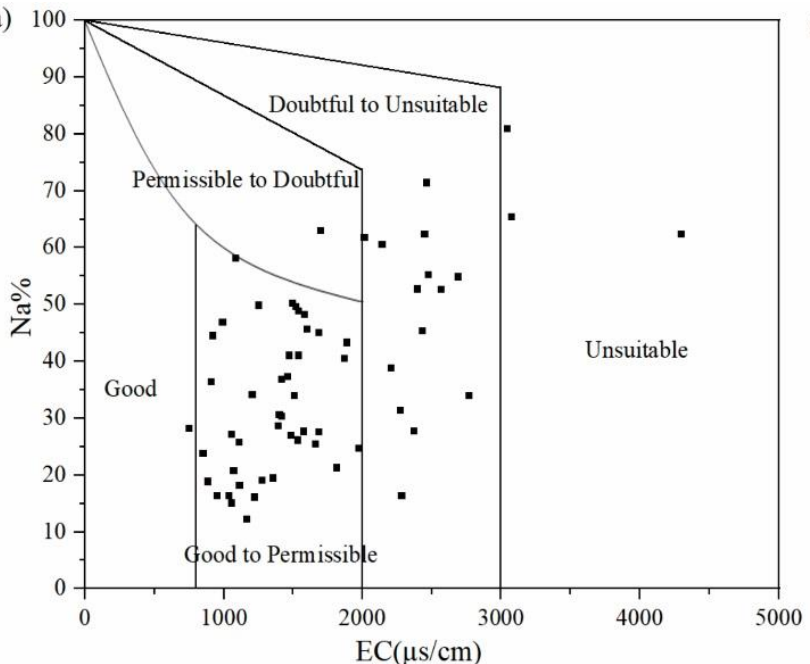

(b)

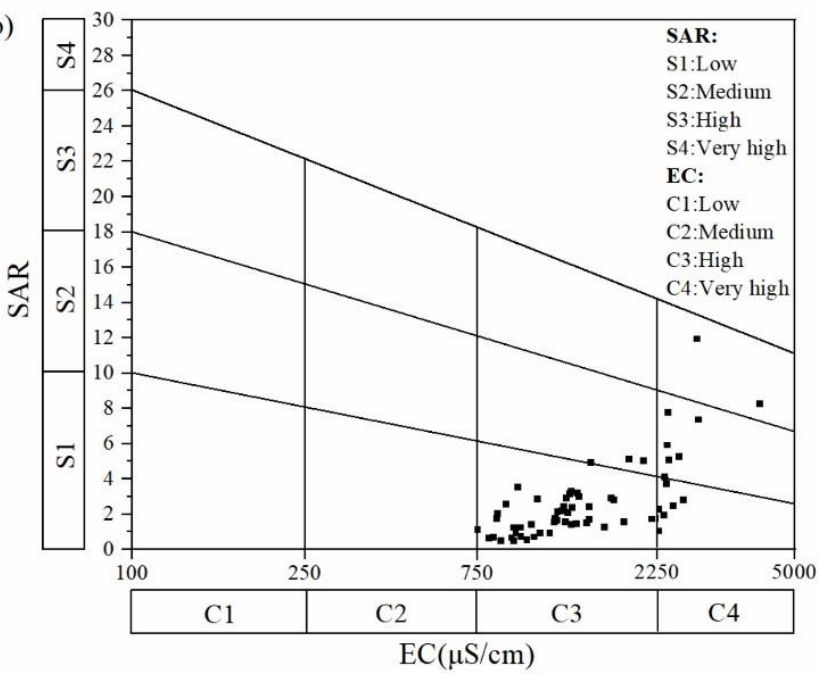

640 Fig. 5 Wilcox diagram (a) and USSL diagram (b) for the assessment of the shallow groundwater

641 quality for irrigation in the study area. 

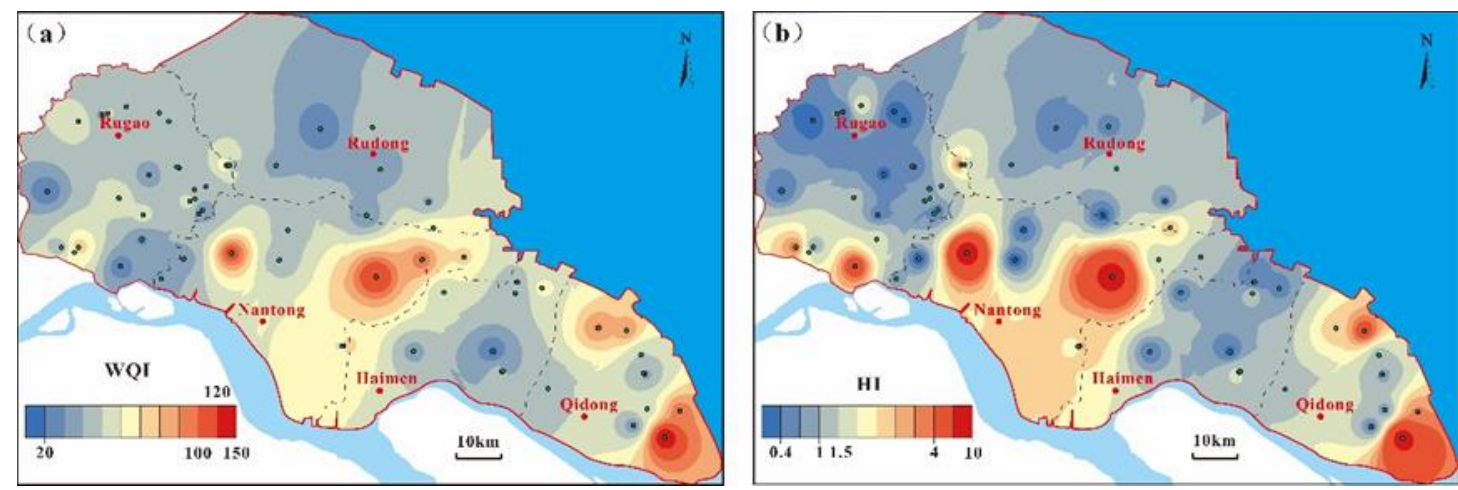

643 Fig. 6 The spatial distribution of WQI value (a) and HI value (b) in the study area. 


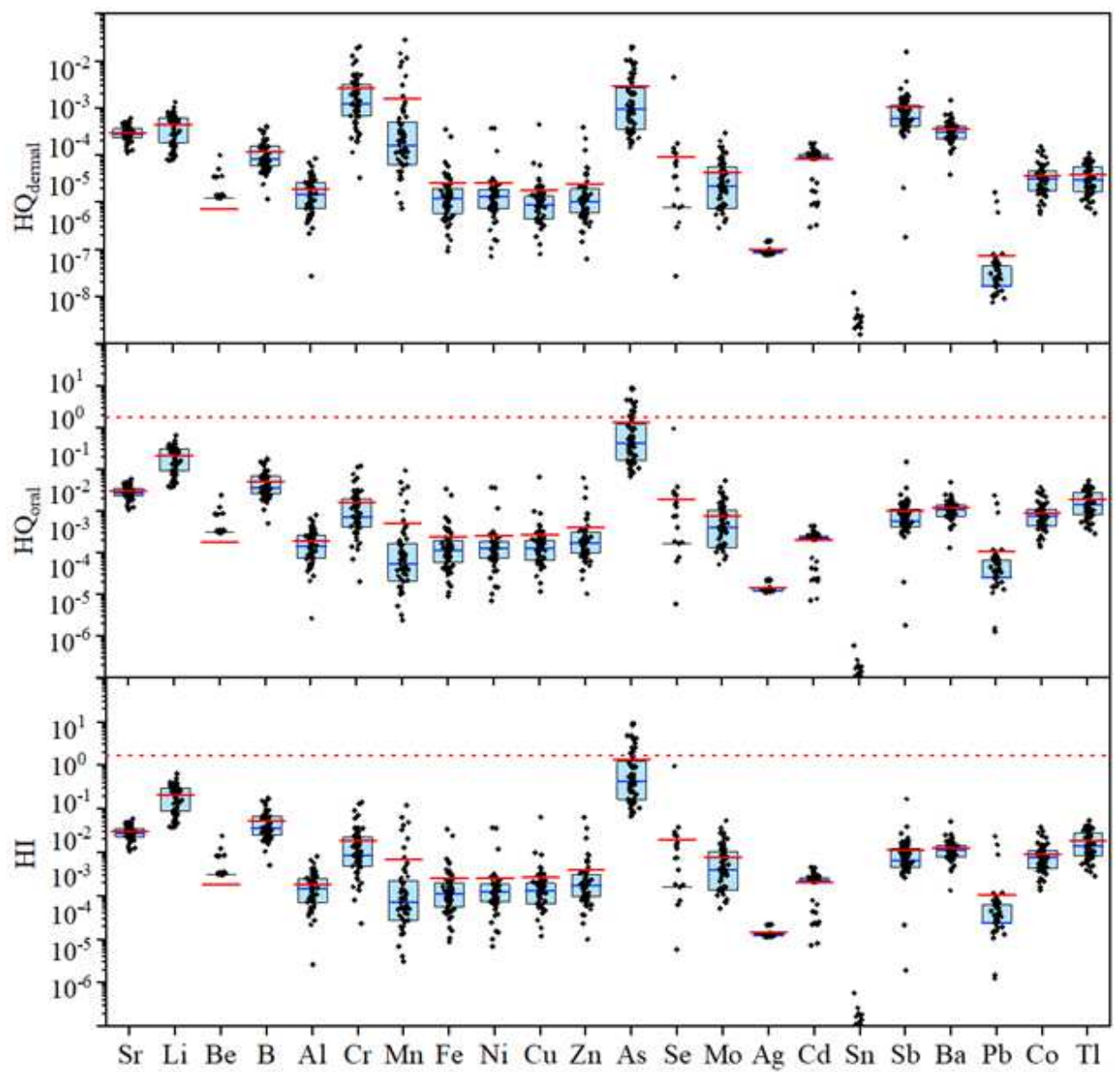

645 Fig. 7 Non-carcinogenic risks in children from different exposure routes (dermal absorption and 646 oral ingestion). 


\section{Supplementary Files}

This is a list of supplementary files associated with this preprint. Click to download.

- LuetalSupplementaryMaterialfinal.docx 